Michą HEJBUDZKI ${ }^{1}$

\title{
Umowa dotycząca dostawy mleka surowego jako instrument prawny systemu organizacji rynku mleka i przetworów mlecznych w Polsce
}

\section{Wprowadzenie}

Budowa jurydycznych podstaw funkcjonowania rynku mleka i przetworów mlecznych stanowi konsekwencję realizacji $\mathrm{WPR}^{2}$. Podobnie jak inne branżowe rynki rolne, rynek mleka i przetworów mlecznych został poddany administracyjnoprawnym instrumentom oddziaływania, których celem było zmniejszenie zachwiania równowagi między podażą i popytem na tym rynku oraz powstałych w jego wyniku nadwyżek strukturalnych ${ }^{3}$, a tym samym osiągnięcie lepszej równowagi rynku. W katalogu narzędzi interwencyjnych służących do stabilizowania rynku mleka i przetworów mlecznych należy wymienić przede wszystkim system kwot mlecznych ${ }^{4}$ i zwią-

$1 \quad$ Uniwersytet Warmińsko-Mazurski w Olsztynie.

2 Do najważniejszych aktów prawnych stanowiących filar tego rynku należy zaliczyć zwłaszcza: rozporządzenie Rady nr 13/1964 z 5.02.1964 r. w sprawie stopniowego ustanowienia wspólnej organizacji rynku mleka i przetworów mlecznych, Dz.Urz. WE 34 z 27.02.1964 r., s. 549-561, które zostało uchylone przez rozporządzenie Rady nr 804/1968 z 27.06.1968 r. w sprawie wspólnej organizacji rynku mleka i przetworów mlecznych, Dz.Urz. WE L 148 z 28.06.1968 r., s. 13-23, które zostało zastąpione rozporządzeniem Rady (WE) nr 1255/1999 z 17.05.1999 r. w sprawie wspólnej organizacji rynku mleka i przetworów mlecznych, Dz.Urz. WE L 160 z 26.06.1999 r., s. 4872, które zostało uchylone przez rozporządzenie Rady (WE) nr 1234/2007 z 22.10.2007 r. ustanawiające wspólną organizację rynków rolnych oraz przepisy szczegółowe dotyczące niektórych produktów rolnych, Dz.Urz. UE L 299 z 16.11.2007 r., s. 1-149 (dalej: rozp. 1234/2007), które zostało uchylone przez rozporządzenie PE i Rady (UE) nr 1308/2013 z 17.12.2013 r. ustanawiające wspólną organizację rynków produktów rolnych oraz uchylające rozporządzenia Rady (EWG) nr 922/72, (EWG) nr 234/79, (WE) nr 1037/2001 i (WE) nr 1234/2007, Dz.Urz. UE L 347 z 20.12.2013 r., s. 671-854 (dalej: rozporządzenie 1308/2013).

3 M. Ciepielewska, Wspólna Polityka Rolna EWG, Warszawa 1981, s. 97; P. Czechowski, Proces dostosowania polskiego prawa rolnego i żywnościowego do prawa Unii Europejskiej, Warszawa 2001, s. 209; B. Jeżyńska, Rynek mleka i przetworów mlecznych, (w:) Prawo rolne i żywnościowe. Zarys wykładu, B. Jeżyńska, A. Oleszko (red.), Zakamycze 2003, s. 264.

4 M. Buchowiecki, Wspólna Polityka Rolna EWG w latach osiemdziesiątych, Warszawa 1991, s. 67-70; E. Tomkiewicz, Kwoty mleczne jako forma reglamentowania rolniczej działalności gospodarczej, „Studia luridica Agraria” 2000, T. 1, s. 135-148; E. Tomkiewicz, Prawna organizacja rynku mleka i jego przetworów, (w:) Wspólna Polityka Rolna. Zagadnienia prawne, A. Jurcewicz, B. Kozłowska, E. Tomkiewicz (red.), Warszawa 2007, s. 111-115; B. Jeżyńska, Producent rolny jako przedsiębiorca, Lublin 2008, s. 123-126; M. Szewczak, Administracyjno-prawne aspekty realizacji Wspólnej Polityki Rolnej w Polsce, Lublin 2008, s. 121; E. Tomkiewicz, Instrumenty ograniczania nadprodukcji rolnej, (w:) Prawo i polityka rolna Unii Europejskiej, A. Jurcewicz (red.), Warszawa 2010, s. 71-74. 
zane z ustalaną ilością referencyjną opłaty wyrównawcze ${ }^{5}$, ale także m.in. subwencje, cenę docelową oraz cenę progową ${ }^{6}$.

Skutkiem uzgodnionych w latach 2003-2004 i kontynuowanych później reform WPR był postępujący proces deregulacji rynku mleka i przetworów mlecznych ${ }^{7}$. Zauważono, że z uwagi na wysoki popyt wewnętrzny i zewnętrzny system kwot mlecznych ogranicza rozwój produkcji w odróżnieniu od sytuacji, która miała miejsce w momencie wprowadzania kwot jako odpowiedzi na nadprodukcję $e^{8}$. W rezultacie kwoty stały się przyczyną zmniejszania prorynkowego nastawienia producentów mleka, ponieważ zakłócały ich reakcję na sygnały cenowe i uniemożliwiały uzyskanie większej skuteczności w sektorze, gdyż hamowały restrukturyzację ${ }^{9}$. Dążenie do poprawy konkurencyjności mleka i przetworów mlecznych na rynkach międzynarodowych skutkowało zmniejszeniem poziomu wsparcia rynku, w szczególności poprzez stopniową redukcję, począwszy od 1 lipca 2004 r., cen interwencyjnych masła i mleka odtłuszczonego w proszku, ustanowionych w rozporządzeniu Rady (WE) nr 1255/1999, czego wyrazem było m.in. dostosowanie relatywnego poziomu ceny interwencyjnej tych dwóch produktów oraz zniesienie ceny docelowej ${ }^{10}$, przy jednoczesnym wsparciu producentów mleka premiami mlecznymi i płatnościami dodatkowymi ${ }^{11}$, ostatecznie włączonymi do mechanizmu

Rozporządzenie Rady (EWG) nr 856/84 z 31.03.1984 r. zmieniające rozporządzenie nr 804/1968 z 27.06.1968 r. w sprawie wspólnej organizacji rynku mleka i przetworów mlecznych, Dz.Urz. WE L 90 z 1.04.1984 r., s. 1012 wprowadziło od 2 kwietnia 1984 r. dodatkowy system opłat wyrównawczych w tym sektorze, który polegał na stosowaniu opłaty wyrównawczej do ilości mleka skupionego lub sprzedanego do bezpośredniej konsumpcji przekraczającej pewien próg gwarancji ustalany w stosunku do każdego państwa członkowskiego jako gwarantowana całkowita ilość dla referencyjnej zawartości tłuszczu w mleku. System ten został kilkakrotnie rozszerzony, w szczególności rozporządzeniem Rady (EWG) nr 3950/92 z 28.12.1992 r. ustanawiającym dodatkową opłatę wyrównawczą w sektorze mleka i przetworów mlecznych, rozporządzeniem Rady (WE) nr 1256/1999 z 17.05.1999 r. zmieniającym rozporządzenie (EWG) nr 3950/92 ustanawiające dodatkową opłatę wyrównawczą w sektorze mleka i przetworów mlecznych oraz rozporządzeniem Rady (WE) nr 1788/2003 z 29.09.2003 r. ustanawiającym opłatę wyrównawczą w sektorze mleka i przetworów mlecznych, Dz.Urz. UE L 270 z 21.10.2003 r., s. $123-136$.

6 Szerzej zob. P. Czechowski, Rynek mleka i przetworów mlecznych, (w:) Polskie prawo rolne na tle ustawodawstwa Unii Europejskiej, P. Czechowski, M. Korzycka-Iwanow, S. Prutis, A. Stelmachowski (red.), Warszawa 1994, s. 206-207.

7 Szerzej zob. E. Tomkiewicz, Wspólna polityka rolna po reformie z 2003 r., „Studia luridica Agraria” 2005, T. V, s. 219; W. Guba, J. Dąbrowski, Deregulacja rynku mleka w Unii Europejskiej - Skutki i zalecenia dla Polski, Roczniki Nauk Rolniczych, Seria G - Ekonomika Rolnictwa, 2012, t. 99, z. 11, s. 33.

8 Mimo to system kwot produkcyjnych w sektorze mleka i przetworów mlecznych został utrzymany w rozporządzenie 1234/2007, zob. m.in. pkt 30, pkt 36, pkt 37.

9 Zob. pkt 8 rozporządzenia Rady (WE) nr 72/2009 z 19.01.2009 r. w sprawie zmian we wspólnej polityce rolnej poprzez zmianę rozporządzeń (WE) nr 247/2006, (WE) nr 320/2006, (WE) nr 1405/2006, (WE) nr 1234/2007, (WE) nr 3/2008 oraz (WE) nr 479/2008 i uchylającego rozporządzenia (EWG) nr 1883/78, (EWG) nr 1254/89, (EWG) nr 2247/89, (EWG) nr 2055/93, (WE) nr 1868/94, (WE) nr 2596/97, (WE) nr 1182/2005 i (WE) nr 315/2007, Dz.Urz. UE L 30 z 31.01.2009 r., s. 1-15.

10 Zob. pkt 2 i 3 rozporządzenia Rady (WE) nr 1787/2003 z 29.09.2003 r. zmieniającego rozporządzenie (WE) nr 1255/1999 w sprawie wspólnej organizacji rynku mleka i przetworów mlecznych, Dz.Urz. UE L 270 z 21.10.2003 r., s. 121-122.

11 Zob. m.in. art. 95 i 96 rozporządzenia Rady (WE) nr 1782/2003 z 29.09.2003 r. ustanawiającego wspólne zasady dla systemów wsparcia bezpośredniego w ramach wspólnej polityki rolnej i ustanawiającego określone systemy wsparcia dla rolników oraz zmieniającego rozporządzenia (EWG) nr 2019/93, (WE) nr 1452/2001, (WE) nr 1453/2001, (WE) nr 1454/2001, (WE) nr 1868/94, (WE) nr 1251/1999, (WE) nr 1254/1999, (WE) nr 1673/2000, (EWG) nr 2358/71 i (WE) nr 2529/2001, Dz.Urz. UE L 270 z 21.10.2003 r., s. 1-69. 
jednolitych płatności ${ }^{12}$. Reformy wspólnej organizacji rynków obejmujące mleko i przetwory mleczne miały na celu orientację rynkową, $\mathrm{tj}$. umożliwienie, aby sygnały cenowe kierowały decyzjami rolników o tym, co i ile produkować, tak aby wzmocnić konkurencyjność sektora mleczarskiego oraz jego zrównoważony rozwój w kontekście zglobalizowanego handlu, co miało doprowadzić do podniesienia wydajności i umożliwić temu sektorowi UE skorzystanie z możliwości rynkowych w UE i poza nią. Wyrazem tych zmian było stopniowe zwiększanie kwot, aby zapewnić sprawne wycofanie systemu kwot mlecznych do 2015 r. $^{13}$, co ostatecznie nastąpiło z upływem 31 marca 2015 r. $^{14}$

Przedstawione działania w zasadzie pozbawiały rolników z UE ochrony tak w wymiarze europejskim, jak też światowym, którą do tej pory zapewniała im izolacja od rynku globalnego i zorganizowane formy zarządzania rynkiem mleka i przetworów mlecznych przewidziane w ramach prowadzenia WPR ${ }^{15}$. Liberalizacja reguł działania tego rynku zwróciła uwagę unijnego regulatora na konieczność zbudowania unormowań osłonowych o zróżnicowanym wymiarze dla producentów mleka. W obszarze stosunków ściśle handlowych dotyczących rynku mleka i przetworów mlecznych punktem wyjścia dla prac legislacyjnych był fakt, że koncentracja dostaw jest znacznie niższa niż koncentracja przetwarzania, co zakłóca równowagę w sile przetargowej w łańcuchu dostaw między rolnikami a zakładami mleczarskimi i może prowadzić do nieuczciwych praktyk rynkowych. Szczególne znaczenie miała okoliczność, że w momencie dostarczania mleka rolnicy często nie wiedzieli, jaką otrzymają za nie cenę, gdyż zakłady mleczarskie określały ją znacznie później w oparciu o czynniki pozostające całkowicie poza kontrolą rolników. W rezultacie dystrybucja wartości dodanej w łańcuchu nie była zrównoważona, w szczególności w odniesieniu do rolników, co generowało problem transmisji cen wzdłuż łańcucha ${ }^{16}$. Ponieważ potrzeba przywrócenia, a w dalszej perspektywie czasowej utrzymania, równowagi w obszarze siły przetargowej najbardziej ujawniała się na odcinku pomiędzy rolnikami a przetwórcami, wysiłek legislacyjny unijnego prawodawcy skoncentrowany był na wypracowaniu jurydycznych figur służących roz-

Art. 71i rozporządzenia Rady (WE) nr 583/2004 z 22.03.2004 r. zmieniającego rozporządzenie (WE) nr 1782/2003 ustanawiające wspólne zasady dla mechanizmów bezpośredniego wsparcia w ramach wspólnej polityki rolnej i ustanawiające określone mechanizmy wsparcia dla rolników, rozporządzenie (WE) nr 1786/2003 w sprawie wspólnej organizacji rynku suszu paszowego i rozporządzenie (WE) nr 1257/1999 w sprawie wsparcia rozwoju obszarów wiejskich z Europejskiego Funduszu Orientacji i Gwarancji Rolnej (EFOGR) w związku z przystąpieniem Cypru, Estonii, Litwy, Łotwy, Malty, Polski, Republiki Czeskiej, Słowacji, Słowenii i Węgier do Unii Europejskiej, Dz.Urz. UE L 91 z 30.03.2004 r., s. 1-14.

13 Zob. pkt 8 rozporządzenia nr 72/2009 oraz M. Śmigla, Stan i perspektywy rozwoju rynku mleka w Unii Europejskiej w świetle zniesienia kwot mlecznych, Folia Pomeranae Universitatis Technologiae Stetinensis. Oeconomica 2013, nr 70, s. 238-239.

14 Art. 230 ust. 1 lit. a rozporządzenia 1308/2013.

15 L. Russo, Reforma WPR z 2013 r. i stosunki umowne pomiędzy uczestnikami rynku, „Przegląd Prawa Rolnego” 2014, nr 2, s. 154.

16 Zob. wniosek rozporządzenie Parlamentu Europejskiego i Rady zmieniające rozporządzenie Rady (WE) nr 1234/2007 w odniesieniu do stosunków umownych w sektorze mleka i przetworów mlecznych, COM/2010/0728. 
wiązaniu tych kwestii. W następstwie wprowadzone rozwiązania prawne przyjęły charakter obligatoryjny oraz fakultatywny ${ }^{17}$.

Do grupy tych pierwszych należy zaliczyć nałożony na państwa członkowskie $\mathrm{UE}^{18}$ obowiązek wdrożenia stosownych przepisów, które umożliwią: 1) uznawanie organizacji producentów mleka, w tym organizacji międzynarodowych oraz kontrolę ich działalności; 2) zbieranie miesięcznych danych dotyczących ilości mleka, które zostało skupione przez podmioty skupujące, i przesyłanie ich w odpowiednim zakresie, formie i terminie Komisji Europejskiej, począwszy od 1 kwietnia 2015 r. ${ }^{19}$

Z kolei rozwiązaniami o charakterze fakultatywnym, których realizacja została pozostawiona do dobrowolnej decyzji każdego państwa członkowskiego, są: 1) uznawanie zrzeszeń uznanych organizacji producentów w sektorze mleka i przetworów mlecznych; 2) uznawanie międzybranżowych organizacji w sektorze mleka i przetworów mlecznych; 3) wprowadzenie na terytorium danego państwa członkowskiego obowiązku objęcia każdej dostawy mleka surowego przez rolnika do przetwórcy pisemną umową lub wprowadzenie wymogu, aby pierwsi skupujący zobowiązani byli do złożenia pisemnej oferty zawarcia umowy o dostawę mleka surowego przez rolników; 4) wdrożenie na określony czas przepisów regulujących podaż sera korzystającego z chronionej nazwy pochodzenia lub chronionego oznaczenia geograficznego.

Szerokie rozumienie pojęcia stosunków umownych w sektorze mleka i przetworów mlecznych nakazuje włączenie do ich zakresu również regulacji prawnych dotyczących negocjacji umownych, a także uznanych organizacji producentów w sektorze mleka i przetworów mlecznych oraz zrzeszeń takich organizacji producentów. W niniejszym opracowaniu przyjęto jednak wąskie rozumienie tego terminu, ograniczając jego zakres do prawnych aspektów związanych z treścią i formą umów dotyczących dostarczania mleka. Taki wybór został podyktowany systematyką unijnych aktów prawnych, które w ten sposób określiły znaczenie tego pojęcia ${ }^{20}$.

Celem rozważań zawartych w niniejszym opracowaniu jest ukazanie procesu legislacyjnego, którego efektem jest wykreowanie przepisów szczególnych regulujących umowy dotyczące dostaw mleka surowego, które stanowią instrument od-

17 Rozporządzenie PE i Rady (UE) nr 261/2012 z 14.03.2012 r. w sprawie zmiany rozporządzenia (WE) nr 1234/2007 w odniesieniu do stosunków umownych w sektorze mleka i przetworów mlecznych, Dz.Urz. UE L 94 z 30.03.2012 r., s. 38-48 (dalej: rozporządzenie. 261/2012).

W Polsce stosowne zmiany zostały dokonane ustawą z dnia 13 września 2013 r. o zmianie ustawy o organizacji rynku mleka i przetworów mlecznych, Dz.U. z 2013 r. poz. 1272, zob. też Druk Sejmu VII, nr 1589.

19 Szczegóły rozwiązania na poziomie unijnym zostały określone przez rozporządzenie wykonawcze Komisji (UE) nr 511/2012 z 15.06.2012 r. w sprawie powiadomień dotyczących organizacji producentów i organizacji międzybranżowych oraz negocjacji umownych i stosunków umownych określonych w rozporządzeniu Rady (WE) nr 1234/2007 w odniesieniu do sektora mleka i przetworów mlecznych, Dz.Urz. UE L 156 z 16.06.2012 r., s. 3940 oraz rozporządzenie delegowane Komisji (UE) nr 880/2012 z 28.06.2012 r. uzupełniające rozporządzenie Rady (WE) nr 1234/2007 w odniesieniu do współpracy międzynarodowej i negocjacji umownych organizacji producentów w sektorze mleka i przetworów mlecznych, Dz.Urz. UE L 263 z 28.09.2012 r., s. 8-9. Zob. art. 185 fozporządzenia $\mathrm{nr} 1234 / 2007$ oraz art. 148 rozporządzenia nr 1308/2013. 
Umowa dotycząca dostawy mleka surowego jako instrument prawny...

działywania na rynek mleka i przetworów mlecznych oraz zwrócenie uwagi na najistotniejsze aspekty ich wprowadzenia do polskiego systemu prawnego.

\section{Regulacja stosunków umownych w sektorze mleka i przetworów mlecznych na poziomie UE}

Potrzeba odwołania się do regulacji unijnych wynika z faktu, że są one źródłem krajowych unormowań prawnych państw UE dotyczących systemu umownego w sektorze mleka i przetworów mlecznych. Podstawowe znaczenie w tym zakresie należy przypisać nowelizacji rozporządzenia 1234/2007²1, której istota polegała na umożliwieniu państwom członkowskim wprowadzenia przepisów dotyczących stosunków umownych celem właściwego funkcjonowania rynku wewnętrznego. Mianowicie, jeżeli państwo członkowskie postanowiło, że na jego terytorium każda dostawa mleka surowego przez rolnika do przetwórcy mleka surowego musiała być przedmiotem pisemnej umowy między stronami lub postanowiło, że pierwsi skupujący muszą złożyć pisemną ofertę zawarcia umowy o dostawę mleka surowego przez rolników, taka umowa lub taka oferta musiała spełniać warunki określone w tym rozporządzeniu. Jednocześnie zostało przyjęte, że jeżeli państwo członkowskie postanowiło, iż dostawy mleka surowego przez rolnika do przetwórcy mleka surowego musiały być przedmiotem pisemnej umowy między stronami, musiało ono również postanowić o tym, który etap lub etapy dostawy są objęte taką umową, jeżeli dostawa mleka surowego była dokonywana za pośrednictwem jednego lub większej liczby nabywców. Na użytek tych regulacji termin ,nabywca” został zdefiniowany jako przedsiębiorstwo, które przewozi surowe mleko od rolnika lub innego skupującego do przetwórcy mleka surowego lub innego nabywcy, a w każdym takim przypadku ma miejsce przeniesienie prawa własności do mleka surowego ${ }^{22}$.

Art. $185 f$ ust. 2 rozporządzenia 1234/2007 zawierał warunki, które musiała spełniać oferta lub umowa. Przede wszystkim powinny one być sporządzone w formie pisemnej jeszcze przed dostawą oraz zawierać pewne minimum treści. Jednym z najważniejszych elementów była cena dostawy, która powinna być stała i określona w umowie lub obliczana poprzez połączenie różnych czynników określonych w umowie, które mogły obejmować wskaźniki rynku odzwierciedlające zmianę warunków na rynku, dostarczoną ilość oraz jakość lub skład dostarczonego mleka surowego. Poza tym do obligatoryjnych składników umowy lub oferty unijny ustawodawca zaliczył: 1) określenie ilości mleka surowego, którą można było dostarczyć lub która musiała zostać dostarczona, wraz z terminem takich dostaw; 2) okres obowiązywania umowy, który mógł być ograniczony lub nieograniczony z klauzulami o rozwiązaniu umowy; 3 ) szczegóły dotyczące procedur i terminów płatności; 4)

21 Nowelizacja została dokonana przez rozporządzenie PE i Rady (UE) nr 261/2012, Dz.Urz. UE L 94 z 30.03.2012 r., s. 38-48, którego art. 1 ust. 7 wprowadził art. $185 f$ do rozporządzenia nr 1234/2007.

22 Zgodnie $z$ art. 2 ust. 2 rozporządzenia nr 261/2012 art. $185 f$ miał być stosowany od 3 października 2012 r. 
ustalenia dotyczące odbioru lub dostawy mleka surowego; 5) przepisy mające zastosowanie w przypadku zaistnienia siły wyższej. Zarówno przytoczone elementy umów o dostawę mleka surowego zawieranych przez rolników, nabywców mleka surowego lub przetwórców mleka surowego, jak też wszystkie pozostałe, które strony chciały włączyć, miały podlegać swobodnym negocjacjom między nimi.

Jeśli państwo członkowskie postanowiło wprowadzić obowiązek zawierania pisemnej umowy o dostawę, to mogło też określić minimalny okres obowiązywania, który miał zastosowanie wyłącznie do umów pisemnych między rolnikiem i pierwszym skupującym mleko surowe. Taki minimalny okres obowiązywania umowy powinien wynosić co najmniej sześć miesięcy i nie mógł zakłócać właściwego funkcjonowania rynku wewnętrznego. Natomiast jeżeli państwo członkowskie postanowiło, że pierwszy skupujący mleko surowe musi złożyć pisemną ofertę umowy rolnikowi, mogło postanowić, że oferta musi obejmować minimalny okres obowiązywania umowy określony w tym celu przez prawo krajowe. Taki minimalny okres obowiązywania wynosił co najmniej sześć miesięcy i nie mógł zakłócać właściwego funkcjonowania rynku wewnętrznego. Ustalenie minimalnego okresu związania stron umową nie mogło jednak przybrać charakteru bezwzględnego, rolnik miał prawo do sprzeciwienia się stosowaniu takiego minimalnego czasu obowiązywania, pod warunkiem, że złożył taki sprzeciw na piśmie. W takim przypadku strony miały swobodę negocjacji wszystkich elementów umowy, nawet tych obligatoryjnych wymienionych w art. 185 f ust. 2 lit. c) rozporządzenia 1234/2007.

Na zasadzie odstępstwa od art. 185f ust. 1 rozporządzenia 1234/2007 umowa lub oferta umowy nie były wymagane, gdy mleko surowe było dostarczane przez rolnika do spółdzielni, której rolnik był członkiem, jeżeli statut tej spółdzielni lub zasady i decyzje w nim zawarte lub z niego wynikające zawierały przepisy o podobnych skutkach do przepisów określonych w ust. 2 lit. a), b) i c).

Przytoczone regulacje przestały formalnie obowiązywać 31 grudnia 2013 r. ${ }^{23}$, ale odegrały kluczową rolę jako baza normatywna służąca za wzór do zbudowania systemu, którego kształt zasadniczo został określony w art. 168 rozporządzenia 1308/2013. Wykładnia przepisów rozporządzenia 1308/2017 prowadzi do wniosku o autonomicznym charakterze jurydycznych podstaw systemu umownego odnoszącego się do sektora mleka i przetworów mlecznych. Wskazuje na to treść art. 148 rozporządzenia 1308/2017, który stanowi lex specialis w stosunku do art. 168 rozporządzenia 1308/2013, zaś pod względem merytorycznym jest powtórzeniem art. 185 fozporządzenia 1234/2007. 


\section{Polskie regulacje stosunków umownych w sektorze mleka i produktów mlecznych}

W Polsce proces autonomizacji rynku mleka i produktów mlecznych ${ }^{24}$ rozpoczął się wraz z przebudową podstaw funkcjonowania rynku rolnego $\mathrm{w}$ związku z transformacją ustrojową zapoczątkowaną w $1989 \mathrm{r}^{25}$ Początkowo interwencję na rynku mleka regulowała ustawa z dnia 7 czerwca 1990 r. o utworzeniu Agencji Rynku Rolnego ${ }^{26}$. Stosowane wówczas instrumenty interwencji na rynku mleka wykazywały głęboki dystans do tych, które były stosowane w UE, zarówno w odniesieniu do rodzaju różnych form interwencji, jak i do zakresu poziomu wsparcia. W Polsce interwencja na rynku mleka ograniczała się do zakupów interwencyjnych masła i odtłuszczonego mleka w proszku oraz subwencji do eksportu OMP, a polski rynek chroniony był systemem cet $^{27}$. Wyrazem dążenia polskiego ustawodawcy do dostosowania krajowego prawa do przepisów unijnych, obejmujących narzędzia prawne obowiązujące na rynku wewnętrznym, była ustawa z dnia 6 kwietnia $2001 \mathrm{r}$. o organizacji rynku mleka i przetworów mlecznych ${ }^{28}$. Znajdujące się w tej ustawie mankamenty co do kwotowania produkcji mleka oraz systemu interwencji rynkowej do rozwiązań stosowanych w państwach UE oraz dublowanie zagadnień, które już były uregulowane w ustawodawstwie unijnym obowiązującym bezpośrednio państwa członkowskie, sprawiły ${ }^{29}$, że została zastąpiona obecnie obowiązującą ustawą z dnia 20 kwietnia 2004 r. o organizacji rynku mleka i przetworów mlecznych ${ }^{30}$.

Rezultatem ewolucji rozwiązań prawnych w tym sektorze rynku rolnego, jak też konsekwencją oddziaływania prawodawstwa unijnego na polski porządek prawny, było wprowadzenie systemu umownego ustawą z dnia 10 lipca 2015 r. o zmianie ustawy o Agencji Rynku Rolnego i organizacji niektórych rynków rolnych oraz niektórych innych ustaw ${ }^{31}$ poprzez dodanie do ustawy z dnia 11 marca 2004 r. o Agencji Rynku Rolnego i organizacji niektórych rynków rolnych ${ }^{32}$ art. 38q, który zaczął obowiązywać od 3 października 2015 r. Istota przyjętego rozwiązania polegała na tym, że każde dostarczenie produktów rolnych sektora mleka i produktów mlecznych, z wyłączeniem sprzedaży bezpośredniej, przez producentów, grupy producentów tych produktów, organizacje takich producentów albo zrzeszenia organizacji

Na temat udziału produkcji mleka w strukturze towarowej produkcji rolniczej zob. W. Ziętara, Organizacja i ekonomika produkcji mleka w Polsce, dotychczasowe tendencje i kierunki zmian, „Roczniki Nauk Rolniczych, Seria G - Ekonomika Rolnictwa" 2012, t. 99, z. 11, s. 43. Szerzej zob. P. Czechowski, Kształtowanie się rynku rolnego w Polsce, (w:) Polskie prawo rolne na tle ustawodawstwa Unii Europejskiej, P. Czechowski, M. Korzycka-Iwanow, S. Prutis, A. Stelmachowski (red.), Warszawa 1994, s. 217-218.

Dz.U. z 1997 r. Nr 142, poz. 951 ze zm.

Druk Sejmu III, nr 3261.

Dz.U. z 2001 r. Nr 129, poz. 1446 ze zm.

Druk Sejmu IV, nr 2560.

Tekst jedn. Dz.U. z 2017 r. poz. 1037 ze zm.

Dz.U. z 2015 r. poz. 1419.

Tekst jedn. Dz.U. z 2017 r. poz. 1006 ze zm., dalej: ustawa z 2004 r. 
takich producentów do pierwszego nabywcy wymagało pisemnej umowy spełniającej warunki określone w art. 148 ust. 2 rozporządzenia 1308/2013. W przypadku gdy pierwszym nabywcą, nie był przetwórca, umowa między kolejnymi nabywcami miała być również zawierana na piśmie. Została też zawarta delegacja ustawowa dla ministra właściwego do spraw rynków rolnych, który na jej podstawie może określić, w drodze rozporządzenia, minimalny okres obowiązywania takiej umowy, mając na względzie zapewnienie właściwego funkcjonowania rynku wewnętrznego ${ }^{33}$.

Funkcjonowanie przyjętych regulacji wyzwoliło potrzebę ich modyfikacji, czego wyrazem stała się ustawa z dnia 7 lipca 2017 r. o zmianie ustawy o Agencji Rynku Rolnego i organizacji niektórych rynków rolnych oraz zmianie niektórych innych ustaw $^{34}$, która w art. 1 pkt 2 ppkt a wprowadziła nowe brzmienie art. $38 \mathrm{q}^{35}$. Najważniejsze zmiany w odniesieniu do sektora mleka i przetworów mlecznych wywołane nowelizacją art. 38q ustawy z 2004 r. sprowadzają się do następujących zagadnień.

Po pierwsze, zostało doprecyzowane pojęcie producenta rolnego. Art. 3 rozporządzenia 1308/2013 do celów stosowania tego rozporządzenia odsyła do definicji zawartych w rozporządzeniu PE i Rady 1307/2013 z 17 grudnia 2013 r. ustanawiającym przepisy dotyczące płatności bezpośrednich dla rolników na podstawie systemów wsparcia w ramach wspólnej polityki rolnej oraz uchylającym rozporządzenie Rady (WE) 637/2008 i rozporządzenie Rady (WE) 73/200936. A zatem pojęcie „rolnik" oznacza osobę fizyczną lub prawną bądź grupę osób fizycznych lub prawnych, bez względu na status prawny takiej grupy i jej członków w świetle prawa krajowego, której gospodarstwo rolne jest położone na terytorium RP, oraz która prowadzi działalność rolniczą. Jurydycznym skutkiem dokonanej zmiany jest to, że umowa na dostarczenie produktów rolnych wymagana będzie wtedy, kiedy jedną ze stron będzie rolnik, którego gospodarstwo rolne jest położone na terenie Polski.

Po drugie, stosowanie systemu umownego w odniesieniu do produktów rolnych sektora mleka i przetworów mlecznych zostało ograniczone do mleka surowego. Wykładnia historyczna wskazuje, że kierunek tej zmiany podyktowany był przekonaniem ustawodawcy o potrzebie uwolnienia spod reżimu art. 38q ustawy z $2004 \mathrm{r}$. produktów przetworzonych ${ }^{37}$. Zważyć jednak należy, że przytoczone wcześniej przepisy unijne odnosiły się wyłącznie do mleka surowego, stąd pierwsza polska regulacja z 2015 r. miała szerszy zakres.

Z dniem 11 lutego 2017 r. art. 38q ust. 4 został zmieniony przez art. 41 pkt 3 lit. b ustawy z dnia 15 grudnia 2016 r. (Dz.U. z 2017 r. poz. 67) w ten sposób, że dodatkowo wyposażył ministra właściwego do spraw rynków rolnych w możliwość określenia w drodze rozporządzenia minimalnego okresu od zawarcia umowy do realizacji dostawy. Jednak do chwili złożenia niniejszego opracowania do druku rozporządzenie takie nie zostało wydane. Dz.U. z 2017 r. poz. 1503.

Zgodnie z art. 11 ustawy nowelizującej, zmieniony art. 38q zaczął obowiązywać od 22 sierpnia $2017 \mathrm{r}$.

Dz.Urz. UE L 347 z 20.12.2013, s. 608, ze zm., dalej: rozporządzenie nr 1307/2013.

Druk Sejmu VIII, nr 1649. 
Po trzecie, rozszerzono katalog form zawarcia umowy także o formę dokumentową i elektroniczną. Nowe rozwiązanie podyktowane było zmianą kodeksu cywilnego ${ }^{38}$, jak również faktem, że wszystkie trzy formy czynności prawnych są obecnie powszechnie stosowane w obrocie towarami rolnymi przez rolników i przedsiębiorców, zaś dopuszczenie jedynie formy pisemnej zawarcia umowy naruszało w sposób istotny funkcjonowanie rynku oraz uniemożliwiało zawieranie szybkich i sprawnych transakcji np. w okresie żniw ${ }^{39}$.

Po czwarte, w zakresie wyłączeń przedmiotowych sprecyzowano, że art. 38q ustawy z 2004 r. nie stosuje się w przypadku sprzedaży bezpośredniej w rozumieniu ustawy z dnia 16 grudnia $2005 \mathrm{r}$. o produktach pochodzenia zwierzęcego ${ }^{40}$.

Po piąte, zostały wprowadzone ograniczenia o charakterze podmiotowym. Mianowicie oprócz przypadku, o którym mowa w art. 148 ust. 3 rozporządzenia 1308/2013, art. 38q ust. 1 ustawy z 2004 r. nie stosuje się również wtedy, gdy producent, o którym mowa w ust. 1, będący członkiem: 1) grupy producentów rolnych w rozumieniu przepisów o grupach producentów rolnych i ich związkach sprzedaje produkty rolne do grupy producentów rolnych, której jest członkiem, 2) organizacji producentów uznanej na podstawie art. 38i ust. 1 lub uznanej w rozumieniu przepisów o organizacji rynku mleka i przetworów mlecznych sprzedaje produkty rolne do tej organizacji - jeżeli statut lub umowa, lub umowa członkowska tej grupy lub tej organizacji spełniają warunki określone w art. 148 ust. 2 lit. a-c tego rozporządzenia. Zmiana podyktowana była tym, że podstawą organizowania się producentów rolnych (np. w grupy producentów rolnych, organizacje producentów) jest wspólne działanie celem dostosowania się do wymagających warunków rynkowych. Jedną z form jest spółdzielnia. Członkowie tychże zorganizowanych form, w ramach aktów założycielskich, umów członkowskich oraz przepisów wewnętrznych mają uregulowane zasady dostarczania produktów na rzecz tych podmiotów (grupy producentów rolnych, organizacje producentów).

Po szóste, na nabywcę mleka surowego został nałożony obowiązek przechowywania umowy przez 2 lata, licząc od końca roku, w którym została zrealizowana ostatnia dostawa w ramach tej umowy. Jest to wymóg wprowadzony dla celów kontroli realizowanych przez KOWR. Brak zdefiniowania obowiązkowego okresu przechowywania tych umów mógłby bowiem skutkować niemożnością naliczenia kary pieniężnej przez organ w odniesieniu do określonych, zrealizowanych dostaw produktów rolnych. ny, ustawy - Kodeks postępowania cywilnego oraz niektórych innych ustaw, Dz.U. z 2015 r. poz. 1311. 
Po siódme, sprecyzowanie w nowelizacji, że umowa wymagana jest na etapie pierwszego nabywcy będącego przetwórcą lub dystrybutorem zdezaktualizowało zawarty w art. 38q ust. 2 ustawy z 2004 r. wymóg pisemnej formy między kolejnymi nabywcami, gdy pierwszym nabywcą nie jest przetwórca, co skutkowało jego uchyleniem.

\section{Wybrane aspekty prawne wprowadzenia przepisów dotyczących stosunków umownych w zakresie dostaw mleka surowego}

Bogactwo problematyki związanej z wprowadzeniem przedstawionych regulacji, w konfrontacji z koniecznością zachowania zwięzłości wywodu, pozwala na węzłowe przedstawienie czterech najbardziej istotnych konsekwencji jurydycznych obowiązywania nowych unormowań.

Pierwsza kwestia dotyczy tego, czy analizowane przepisy wprowadzają do polskiego prawa nowy rodzaj umowy. Na tak postawione pytanie należy udzielić odpowiedzi przeczącej. Przekonuje o tym literalna wykładnia art. 148 rozporządzenia 1308/2013, jak też art. 38q ustawy z 2004 r. Jednak identyfikacja tej umowy skłania do kilku refleksji. Prima facie mogłoby się wydawać, że przepisy te odnoszą się wyłącznie do umowy dostawy, której reżim prawny w polskim porządku normatywnym określają art. 605-612 kc. ${ }^{41} \mathrm{~W}$ art. 148 ust. 1 rozporządzenia 1308/2013 wprost znajduje się sformułowanie o tym, że pierwsi skupujący muszą złożyć: „pisemną ofertę zawarcia umowy o dostawę mleka surowego". Zapewne w praktyce właśnie ten kontrakt będzie występował jako podstawa przekazywania mleka przez rolników. Mimo to należy zauważyć, że w istocie przepisy te nie determinują rodzaju umowy, lecz jedynie określają jej przedmiot. Konstatacja ta pozwala przyjąć tezę, że przytoczone regulacje znajdują zastosowanie do każdego cywilnoprawnego stosunku umownego, którego przedmiotem jest przeniesienie własności mleka surowego w warunkach określonych przez art. 38q ustawy z 2004 r. W konsekwencji wymienione normy w określonych sytuacjach mogą odnosić się przykładowo także do umowy: sprzedaży, kontraktacji oraz umów nienazwanych. Nie istnieją przeszkody, by regulacja ta objęła również umowę zamiany. Wprawdzie art. 148 ust. 2 lit. c ppkt i wymienia cenę jako składnik umowy, ale trzeba ją w tym przypadku rozumieć sensu largo, tj. jako ekwiwalent za dostarczone mleko surowe. Prezentowane stanowisko uzyskuje wsparcie także w wykładni językowej art. 38q ustawy z 2004 r., który stanowi o „każdym dostarczeniu produktów rolnych”. Oznacza to, że również polski ustawodawca przyjął szeroką wykładnię art. 148 rozporządzenia 1308/2013, w której nie ograniczył stosunku prawnego łączącego strony tylko do umowy dostawy. Ratio legis wprowadzenia tych przepisów sprawia jednak, że muszą to być umowy odpłatne. Skoro bowiem celem wprowadzonego tego narzędzia prawnego było za- 
pewnienie producentom lepszego planowania produkcji i dostosowanie jej do zapotrzebowania $^{42}$, a także wzmocnienie pozycji producenta rolnego jako pierwszego ogniwa w łańcuchu dostaw żywności ${ }^{43}$, to niewątpliwie wymogi z art. 38q ustawy z 2004 r. należy odnosić do obrotu gospodarczego z udziałem producentów mleka surowego. Tym samym zakres zastosowania art. 38q ustawy z 2004 r. nie obejmuje umów o charakterze nieodpłatnym, np. darowizny mleka surowego i to nawet wówczas, gdy nabywcą jest dystrybutor w rozumieniu tego przepisu (aczkolwiek zjawisko takie, jako pozbawione ekonomicznego uzasadnienia, będzie miało charakter niezwykle rzadki).

Drugie zagadnienie wiąże się z próbą określenia skutków prawnych niespełnienia jednego lub kilku wymogów wymienionych w art. 148 ust. 2 rozporządzenia 1308/2013 w zw. z art. 38q ust. 1 ustawy z 2004 r. przy zawieraniu umowy. Przyjęta przez ustawodawcę koncepcja dualistycznej ochrony prawnej producenta mleka surowego, realizowana przy równoległym użyciu figur jurydycznych z obszaru prawa prywatnego i prawa publicznego, wymaga dwutorowego odniesienia się do podniesionego zagadnienia.

Wskazany w art. 148 ust. 2 lit. a rozporządzenia 1308/2013 nakaz sporządzenia umowy przed dostawą w zakresie cywilnoprawnych skutków jest irrelewantny. Trzeba bowiem odróżnić sporządzenie umowy od jej zawarcia. Zgodnie z regułami prawa cywilnego, do zawarcia umowy dochodzi wskutek zgodnych oświadczeń woli dwóch stron. Tymczasem w sytuacji, w której przepisy nie przewidują formy szczególnej, albo wymagają formy ad probationem lub ad eventum, sporządzenie umowy jest technicznym aspektem i konsekwencją jej zawarcia. Stąd moment sporządzenia umowy nawet po dostawie nie może niweczyć skutków prawnych powstałego wcześniej między stronami węzła obligacyjnego, skoro właśnie następstwem jego powstania była dostawa.

Treść art. 148 rozporządzenia 1308/2013 ani art. 38q ustawy z 2004 r. nie określa konsekwencji prawnych niezachowania narzuconej prawem formy umowy. Należy jednak dostrzec, że forma pisemna, dokumentowa lub elektroniczna nie jest elementem treści umowy i pozostaje poza jej strukturą. Wprowadzone regulacje nie kreują nowego reżimu prawnego umowy, a jedynie określają dodatkowe obostrzenia, które powinny być stosowane przy zawieraniu przewidzianych prawem kontraktów ${ }^{44}$. O słuszności tego kierunku świadczy także wykładnia historyczna, z której wynika, że wzbogacenie katalogu form zawarcia umowy, dokonane w 2017 r.

W doktrynie został już wyrażony słuszny pogląd o tym, że umowy sprzedaży, dostawy, kontraktacji produktów rolnych zawierane w oparciu o przepisy aktów prawnych organizujących rynki rolne nie przestają być takimi umowami w rozumieniu kc., zob. P. Pytlak, Znaczenie i charakter umów w systemie mechanizmów regulujących branżowe rynki produktów rolnych, „Rejent” 2006, nr 3, s. 103. 
nowelizacją art. 38q ustawy z 2004 r., inspirowane było m.in. zmianami kodeksu cywilnego. Pozwala to wytypować normy prawa cywilnego jako obszar poszukiwania odpowiedzi. A zatem przyjęta forma jest formą ad probationem, zaś jej niezachowanie nie rodzi sankcji w postaci bezwzględnej nieważności. Z takim poglądem koresponduje wykładnia celowościowa i funkcjonalna. Skoro bowiem intencją wprowadzonych przepisów było dążenie do ochrony producentów mleka surowego, to wprowadzenie formy ad solemnitatem uderzałoby przede wszystkim w rolników, którzy zostaliby pozbawieni możliwości wywodzenia przed sądem cywilnym swoich roszczeń ex contractu. Jednocześnie godzi się podkreślić, że na gruncie przepisów prawa cywilnego trudno byłoby szukać podstaw do konstruowania roszczeń $\mathrm{z}$ tytułu niezachowania formy ad probationem.

Na szczególną uwagę zasługują elementy umowy wymienione w art. 148 ust. 2 lit. c rozporządzenia 1308/2013, których charakter prawny jest zróżnicowany. W zależności od rodzaju umowy zawartej na gruncie prawa polskiego niektóre z tych elementów będą miały charakter essentialia negotii, jak np. cena czy ilość mleka surowego, którą można dostarczyć lub która musi zostać dostarczona. Rodzi się pytanie, czy inne elementy, takie jak określenie terminu dostaw mleka surowego, okres związania umową, szczegóły dotyczące terminów i procedur płatności, ustalenia dotyczące odbioru lub dostawy mleka surowego, przyjmą charakter naturalia negotii, czy ich brak powinien skutkować nieważnością umowy po myśli art. $58 \S 1 \mathrm{kc}$. Wydaje się, że właściwe jest pierwsze ze wskazanych rozwiązań. Niezamieszczenie w treści umowy wszystkich elementów wymienionych w art. 148 ust. 2 lit. c rozporządzenia 1308/2013 wpłynie jedynie na kształt wzajemnych praw i obowiązków stron i będzie podlegało ocenie według ogólnych reguł prawa cywilnego w razie sporu sądowego. Nie będzie to jednak sprzeczność z prawem w rozumieniu art. $58 \S 1$ kc., która uzasadniałaby bezwzględną nieważność umowy.

Odmiennie na analizowane zagadnienie należy spojrzeć z perspektywy przepisów zapewniających producentom mleka surowego ochronę o charakterze publicznoprawnym. Niezależnie od rodzaju i rozmiaru skutków cywilnoprawnych, nabycie mleka surowego na podstawie wadliwej umowy uruchomi instrumenty administracyjnoprawne. Określają je przepisy zawarte w rozdziale 9c ustawy z 2004 r., które wprowadziły system kar pieniężnych o zróżnicowanej wysokości zależnej od przewinienia, które wymierza, w drodze decyzji administracyjnej, dyrektor oddziału terenowego KOWR właściwy według miejsca siedziby lub zamieszkania nabywcy albo wnioskodawcy. Kary pieniężne stanowią dochód budżetu państwa i są wpłacane na rachunek bankowy KOWR, w terminie 14 dni od dnia, w którym decyzja o nałożeniu kary stała się ostateczna. Uzupełnieniem tego systemu jest wyposażenie dyrektora oddziału terenowego KOWR właściwego według miejsca siedziby lub za- 
mieszkania nabywcy w prawo przeprowadzania kontroli spełniania obowiązku zawierania umów ${ }^{45}$.

Natomiast należy podkreślić, że żaden organ nie ma uprawnień do uzupełnienia treści umowy o elementy określone w art. 148 ust. 2 rozporządzenia 1308/2013 w przypadku stwierdzenia ich braku. Administracyjnoprawne narzędzia nie pozwalają bowiem na ingerencję w merytoryczną treść łączącego strony stosunku cywilnoprawnego i jego modyfikację. Niepodobna przyjąć, aby jakikolwiek organ, działając w obszarze prawa administracyjnego, mógł określać np. termin dostaw mleka surowego, okres związania umową, szczegóły dotyczące terminów i procedur płatności, albo podejmować ustalenia dotyczące odbioru lub dostawy mleka surowego. Nawet na gruncie prawa cywilnego ingerencja sądu w treść łączącego strony stosunku prawnego ma charakter wyjątkowy i dozwolony tylko na podstawie wyraźnego przepisu, np. art. $357^{1} \mathrm{kc}$.

Dostrzegając potrzebę wprowadzenia ww. regulacji publicznoprawnych należy zauważyć, że wymykają się one spod jednoznacznej oceny.

Zastrzeżenia wzbudza fakt, że zostały one wprowadzone dopiero przez art. 41 ustawy z 2016 r. i zaczęły obowiązywać od 11 lutego 2017 r., a zatem stosunkowo późno w porównaniu z datą wejścia w życie art. 38q ustawy z 2004 roku. Sprawiło to, że w okresie od 3 października 2015 r. do 11 lutego 2017 r. obowiązek stosowania przy dostawach mleka surowego wymogów stawianych przez art. 148 ust. 2 rozp. 1308/2013 był w zasadzie martwy.

Poza tym w niektórych przypadkach razi brak synchronizacji z terminologią i regułami prawa cywilnego. Przykładem jest art. 40i pkt 1b ustawy z 2004 r., który m.in. przewiduje karę pieniężną, jeżeli pierwszy nabywca będący przetwórcą lub dystrybutorem, wbrew przepisom art. 38q ust. 1 lub 1a, nabywa mleko surowe na podstawie umowy niespełniającej warunków określonych w art. 148 ust. 2 lit. c ppkt i rozporządzenia 1308/2013, który to przepis odnosi się do ceny. Rzecz jednak w tym, że w szeregu umów (a zwłaszcza tych, które będą stanowiły podstawę dla dostaw mleka surowego) cena należy do elementów określanych w doktrynie prawa cywilnego jako essentialia negotii, a zatem jej brak powoduje bezskuteczność takiej umowy. W rezultacie, w takim przypadku zapis zawarty w art. 40i pkt 1b ustawy z 2004 r. o nabyciu mleka surowego na podstawie umowy niespełniającej określonych warunków jest wewnętrznie sprzeczny, albowiem w świetle prawa cywilnego umowa taka nie istnieje. Brak określenia ceny sprawia, że nawet jeżeli nastąpiłaby dostawa mleka surowego, to odbyłaby się ona na innej podstawie prawnej, aniżeli umowa. Można się domyślać, że najprawdopodobniej intencją ustawodawcy

45 Podstawę normatywną stanowi art. 38q ust. 3a dodany przez art. 41 pkt 3 lit. a ustawy z dnia 15 grudnia 2016 r. o przeciwdziałaniu nieuczciwemu wykorzystywaniu przewagi kontraktowej w obrocie produktami rolnymi i spożywczymi (dalej: ustawa z 2016 r.) zmieniającej ustawę z 2004 r. z dniem 11 lutego 2017 r. 
była troska o to, aby cena została zawarta w umowie sporządzonej w formie pisemnej, dokumentowej lub elektronicznej. Jeżeli tak właśnie było, to treść analizowanego przepisu nie odzwierciedla takiego zamiaru prawodawcy. Obecnie literalna jego wykładnia skłania do wniosku, że w omawianej sytuacji przewiduje on administracyjnoprawną sankcję za pominięcie określenia ceny, a nie za niezamieszczenie tej ceny w umowie sporządzonej w wymaganej formie.

$\mathrm{Z}$ rezerwą należy też podejść do obecnego brzmienia art. 38q ust. 3a ustawy z 2004 r., którego interpretacja semantyczna uzasadnia pogląd, że dotyczy on jedynie prawa przeprowadzania kontroli spełniania obowiązku zawierania umów, o których mowa w ust. 1. Dopiero rezultaty wykładni przeprowadzonej w oparciu o metodę celowościową pozwalają odczytać intencję ustawodawcy, którą zapewne było poddanie kontroli nie tylko, czy został wykonany obowiązek zawarcia umowy, ale przede wszystkim, czy zawarta umowa jest zgodna $\mathrm{z}$ art. 148 ust. 2 rozporządzenia 1308/2013. Wydaje się, że zmiana redakcji przepisu pozwoliłaby uniknąć tego rodzaju, zbędnych w istocie, wątpliwości.

Trzecie zagadnienie wynika $\mathrm{z}$ faktu, że polski ustawodawca nie zdecydował się na wprowadzenie wymogów dotyczących składania ofert, o których stanowi art. 148 rozporządzenia 1308/2013, co rodzi pytanie, czy w polskich realiach prawnych podlegają one identycznym wymogom jak te, które są przewidziane dla zawieranych umów. Stosownie do art. $66 \S 1 \mathrm{kc}$. oferta jest jednostronnym oświadczeniem woli zawarcia umowy, określającym istotne postanowienia tej umowy. Trudno byłoby założyć a priori, że wszystkie wymogi przewidziane w art. 148 ust. 2 lit. c rozporządzenia 1308/2013 są istotnymi postanowieniami przyszłej umowy. Skłania to do opowiedzenia się za rozstrzyganiem takich kwestii in casu. Jednakże de lege lata w prawie polskim kwestia ta odgrywa wtórne znaczenie wobec braku sankcji i systemu kontroli w tym zakresie, które aktualizują się dopiero po zawarciu umowy.

Czwarta kwestia, która wiąże się bezpośrednio z wprowadzonymi regulacjami, dotyczy ich relacji do trybu postępowania przewidzianego w ustawie z $2016 \mathrm{r}$. Sytuacja braku spełnienia wymogów z art. 38q ustawy z 2004 r. w zw. z art. 148 ust. 2 rozporządzenia 1308/2013 przy zawieraniu umów nierzadko będzie też wyczerpywała znamiona praktyki nieuczciwie wykorzystującej przewagę kontraktową, o której mowa w art. 7 ustawy z 2016 r. Dojdzie wówczas do zbiegu dwóch postępowań administracyjnoprawnych, które będą mogły toczyć się równolegle, a co więcej każde z nich będzie mogło zakończyć się karami finansowymi dla nabywcy mleka surowego ${ }^{46}$. Obowiązujące przepisy nie precyzują wzajemnego wpływu na siebie tych dwóch postępowań, a zwłaszcza możliwości uwzględnienia kary pieniężnej nałoprzewagi kontraktowej - uwagi krytyczne, internetowy „Kwartalnik Antymonopolowy i Regulacyjny” 2017, nr 1, s. $14-15$. 
żonej w jednym postępowaniu na drugie. Rodzi się pytanie o możliwość potraktowania postępowania przewidzianego w ustawie z 2004 r. jako lex specialis wobec tego z ustawy z 2016 r. Odpowiedź nie jest oczywista i wymaga odrębnego zbadania. Jednak już na tym etapie rozważań daje się zauważyć, że pozytywna odpowiedź mogłaby spowodować liczne wątpliwości i nieporozumienia w zakresie subsumpcji poszczególnych stanów faktycznych, a ponadto kolidować z treścią art. 4 ustawy z 2016 r.

\section{Podsumowanie}

Przyjęte w ramach rozporządzenia 1308/2013 rozwiązania, w tym dotyczące stosunków umownych w sektorze mleka i przetworów mlecznych, są wyrazem realizacji działań WPR w ramach tzw. kontraktualizacji ${ }^{47}$. Nie uchroniły one producentów mleka przed niekorzystnymi konsekwencjami uwolnienia tego rynku. Dlatego już od września 2014 r. Komisja UE nieprzerwanie stosuje instrumenty osłonowe, zaś od lipca 2015 r. odtłuszczone mleko w proszku jest oferowane w ramach interwencji publicznej ${ }^{48}$. Jednak przebudowa normatywnego systemu organizacji rynku mleka i produktów mlecznych była skutkiem zapotrzebowania podyktowanego zmieniającą się sytuacją gospodarczą i troską o możliwie optymalne rozwiązania prawne, w ramach których mieli funkcjonować rolnicy z UE.

Omawiane w niniejszym opracowaniu aspekty stanowią tylko niewielką część mozaiki instrumentów prawnych służących producentom mleka surowego. Mimo że nie został im nadany priorytetowy charakter w katalogu przyjętych rozwiązań, to nie powinno to prowadzić do marginalizowania ich znaczenia. Wprowadzony do polskiego prawa z dniem 3 października 2015 r. model systemu umownego był wadliwy. Bez wsparcia w postaci instrumentów z zakresu prawa publicznego przepisy konstruujące system umowny w praktyce nie były przestrzegane, ponieważ ich skuteczność warunkowana była mechanizmem kontroli oraz systemem sankcji, których brakowało. Z kolei ich wprowadzenie od 11 lutego 2017 r. ukazało niedoskonałość rozwiązań przyjętych w art. 38q ustawy z 2004 r., które okazały się zbyt formalistyczne i niewyważone. Pojawiło się niebezpieczeństwo zachwiania równowagi w łańcuchu dostaw żywności w ten sposób, że unormowania te rodziły ryzyko, iż zniechęcą do nabywania niewielkich ilości mleka surowego, co mogło się negatywnie odbijać na małych i średnich producentach rolnych, do których przede wszystkim skierowana była ochrona przewidziana tymi przepisami. Niewielki upływ czasu od wejścia w życie w dniu 22 sierpnia 2017 r. nowelizacji art. 38q ustawy z 2004 r.

47 R. Budzinowski, Problemy ogólne prawa rolnego. Przemiany podstaw legislacyjnych i koncepcji doktrynalnych, Poznań 2008, s. 143; R. Budzinowski, A. Suchoń, K. Błażejewska, Rozwój prawa rolnego w ostatnich latach, „Przegląd Prawa Rolnego” 2011, nr 2, s. 48.

48 Sprawozdanie Komisji dla Parlamentu Europejskiego i Rady, Rozwój sytuacji na rynku mleczarskim i funkcjonowanie przepisów dotyczących „pakietu mlecznego”, COM 2016 (724); zob. też A. Suchoń, Funkcjonowanie rynku mleka po likwidacji kwotowania - wybrane aspekty prawne, „Studia luridica Agraria” 2016, T. XIV, s. 304-310. 
nie pozwala na szerszą ocenę tych zmian. Przyjęta koncepcja wielopłaszczyznowej ochrony rolników produkujących mleko surowe wydaje się z założenia słuszna. Wątpliwości wywołują zagadnienia wynikające z przenikania się przepisów tworzących instrumentarium prawne z zakresu prawa publicznego i prywatnego, których konsekwencją są różne tryby postępowań oraz ich wzajemny wpływ. 
CONTRACT FOR DELIVERY OF RAW MILK AS A LEGAL INSTRUMENT OF THE SYSTEM OF ORGANIZATION OF THE MILK AND MILK PRODUCTS SECTOR IN POLAND

Keywords: milk and milk products sector, contractual relations in the milk and milk products sector, obligation to conclude a written contract on the supply of raw milk, Common Agricultural Policy, unfair use of contractual advantage; dishonest practices, a farmer

Initially, the milk and milk products market was a subject to administrative and legal instruments, with the milk quota system playing a key role. The aim was to reduce the imbalance between the supply and demand and resulting structural surpluses in this sector and thereby to achieve a better market balance.

The reconstruction of the normative system of organization of the milk and milk products sector which began in 2003 resulted from the needs of the changing economic situation and led to a definitive abandonment of the quota system of milk production since 1 April 2015.

The purpose of this paper is to present the legislative process which results in the creation of specific regulations governing the contracts for supply of raw milk which are an instrument influencing the milk and milk products sector and to draw attention to the most important aspects of their introduction into the Polish legal system.

\section{Bibliografia:}

Buchowiecki M., Wspólna Polityka Rolna EWG w latach osiemdziesiątych, Warszawa 1991.

Budzinowski R., Problemy ogólne prawa rolnego. Przemiany podstaw legislacyjnych i koncepcji doktrynalnych, Poznań 2008.

Budzinowski R., Suchoń A., Błażejewska K., Rozwój prawa rolnego w ostatnich latach, „Przegląd Prawa Rolnego" 2011, nr 2.

Ciepielewska M., Wspólna Polityka Rolna EWG, Warszawa 1981.

Czechowski P., Kształtowanie się rynku rolnego w Polsce, (w:) Polskie prawo rolne na tle ustawodawstwa Unii Europejskiej, P. Czechowski, M. Korzycka-Iwanow, S. Prutis, A. Stelmachowski (red.), Warszawa 1994.

Czechowski P., Rynek mleka i przetworów mlecznych, (w:) Polskie prawo rolne na tle ustawodawstwa Unii Europejskiej, P. Czechowski, M. Korzycka-Iwanow, S. Prutis, A. Stelmachowski (red.), Warszawa 1994.

Czechowski P., Proces dostosowania polskiego prawa rolnego i żywnościowego do prawa Unii Europejskiej, Warszawa 2001. 
Guba W., Dąbrowski J., Deregulacja rynku mleka w Unii Europejskiej - Skutki i zalecenia dla Polski, Roczniki Nauk Rolniczych, Seria G - Ekonomika Rolnictwa, 2012, t. 99, z. 11.

Jeżyńska B., Rynek mleka i przetworów mlecznych, (w:) Prawo rolne i żywnościowe. Zarys wykładu, B. Jeżyńska, A. Oleszko (red.), Zakamycze 2003.

Jeżyńska B., Producent rolny jako przedsiębiorca, Lublin 2008.

Jurkowska-Gomułka A., Prezes UOKiK jako organ właściwy w sprawach praktyk nieuczciwego wykorzystania przewagi kontraktowej - uwagi krytyczne, internetowy „Kwartalnik Antymonopolowy i Regulacyjny" 2017, nr 1.

Pytlak P., Znaczenie i charakter umów w systemie mechanizmów regulujących branżowe rynki produktów rolnych, ,Rejent” 2006, nr 3.

Russo L., Reforma WPR z 2013 r. i stosunki umowne pomiędzy uczestnikami rynku, „Przegląd Prawa Rolnego" 2014, nr 2.

Suchoń A., Funkcjonowanie rynku mleka po likwidacji kwotowania - wybrane aspekty prawne, „Studia Iuridica Agraria" 2016, T. XIV.

Szewczak M., Administracyjnoprawne aspekty realizacji Wspólnej Polityki Rolnej w Polsce, Lublin 2008.

Śmigla M., Stan i perspektywy rozwoju rynku mleka w Unii Europejskiej w świetle zniesienia kwot mlecznych, „Folia Pomeranae Universitatis Technologiae Stetinensis. Oeconomica” 2013, nr 70.

Tomkiewicz E., Kwoty mleczne jako forma reglamentowania rolniczej działalności gospodarczej, „Studia Iuridica Agraria” 2000, T. 1.

Tomkiewicz E., Wspólna polityka rolna po reformie z 2003 r., „Studia Iuridica Agraria” 2005, T. V.

Tomkiewicz E., Prawna organizacja rynku mleka i jego przetworów, (w:) Wspólna Polityka Rolna. Zagadnienia prawne, A. Jurcewicz, B. Kozłowska, E. Tomkiewicz (red.), Warszawa 2007.

Tomkiewicz E., Instrumenty ograniczania nadprodukcji rolnej, (w:) Prawo i polityka rolna Unii Europejskiej, A. Jurcewicz (red.), Warszawa 2010.

Ziętara W., Organizacja i ekonomika produkcji mleka w Polsce, dotychczasowe tendencje i kierunki zmian, „Roczniki Nauk Rolniczych, Seria G - Ekonomika Rolnictwa” 2012, t. 99, z. 11. 